\title{
Clinicopathological characteristics and prognosis of signet ring cell carcinoma of the gallbladder
}

\author{
Shijie Wang, Jiayi Li, Jun You and Yanming Zhou*
}

\begin{abstract}
Background: Signet ring cell carcinoma (SRC) is a rare histological subtype of gallbladder adenocarcinoma. The current study evaluates the clinicopathologic features and prognosis of SRC.

Methods: Patients with adenocarcinoma of the gallbladder were identified in the Surveillance, Epidemiology, and End Results database from 1973 to 2016. Overall survival (OS) and cancer-specific survival (CSS) of patients who had SRC were compared with those of patients who had non-SRC using Cox regression and propensity score methods.

Results: Of 22,781 gallbladder adenocarcinomas retrieved, 377 (1.7\%) were SRC and the other 22,404 were non-SRC. SRC was more significantly associated with older age, female gender, poor differentiation, advanced tumor stage, lymph node metastasis, distant metastasis, and advanced AJCC stage. The 5-year OS and CSS in the SRC group were 7.2 and $6.5 \%$, respectively, both of which were significantly worse than the 13.2 and $13.3 \%$ seen in the SRC group ( $P=0.002$ and $P=0.012$, respectively). This survival disadvantage persisted in multivariable analyses [hazard ratio $(H R)=1.256, P=0.021$ and $H R=1.211, P=0.036$ ] and after propensity score matching (OS: $H R=1.341, P=0.012$ and CSS: $H R=1.625, P=0.005)$. Surgery in combination with chemotherapy improved OS of gallbladder SRC patients compared with surgery alone $(H R=0.726, P=0.036)$ or chemotherapy alone $(H R=0.433, P<0.001)$.
\end{abstract}

Conclusion: Patients with SRC of the gallbladder have distinct clinicopathological features with poor prognosis. Surgery in combination with chemotherapy can improve survival.

Keywords: Signet ring cell carcinoma, Gallbladder, Surgery, Prognosis

\section{Background}

Signet ring cell carcinoma (SRC) is an adenocarcinoma in which more than $50 \%$ of the tumor consists of isolated or small groups of malignant cells containing intracytoplasmic mucins [1]. More than 96\% SRCs arise in the stomach, accounting for $11-37 \%$ of all gastric cancers [2-5]. SRC of the gallbladder is extremely rare, and litthe is known about the clinicopathological characteristics, prognosis, and optimal treatment. We sought to address

*Correspondence: zhouymsxy@sina.cn

Department of Hepatobiliary and Pancreatovascular Surgery, The First

Affiliated Hospital of Xiamen University, Xiamen 361003, China this issue through the Surveillance, Epidemiology, and End Results (SEER) database, a large population-based cancer registry.

\section{Methods \\ Data source and study cohort}

The adenocarcinoma of the gallbladder part in the SEER database diagnosed from 1973 to 2016 was the source of present analysis. The diagnosis of SRC and non-SRC was according to the third edition of the International Classification of Disease for Oncology (ICD-O) code 8490 and 8140 respectively. Patients with no follow-up or vital status information were excluded. Meanwhile, patients with 
non-primary tumors and no pathologic diagnosis were excluded. The American Joint Committee on Cancer (AJCC) staging manual (7th edition) was applied in this study. The main outcomes were overall survival (OS) and cancer-specific survival (CSS).

\section{Statistical analysis}

Categorical variables were compared using a Pearson $\chi^{2}$ tests or Fisher exact test. The Kaplan-Meier method was used to calculate survival curves, and the log-rank test was used to identify statistically significant covariates associated with survival in univariate analysis. To identify independent risk factors of survival, multivariate Cox proportional hazard models were applied. In addition, a propensity score matching (PSM) analysis was performed to adjust for all potential baseline confounding variables in the two groups. A $P$ value less than 0.05 was considered statistically significant. Data was analyzed using SPSS (version 24.0; SPSS, Inc., Chicago, IL).

\section{Results}

Of the 22,781 gallbladder asenocarcinomas included in this study, 377 (1.7\%) were SRC and the other 22,404 were non-SRC (Fig. 1). The median follow-up duration was 6 months. At the end of the follow-up period, 3050 patients (13.4\%) were alive, 13,890 patients (61.0\%) died from cancer, and 5841 (25.6\%) patients died of other causes.
The clinicopathological characteristics of the patients are listed in Table 1. SRC was more significantly associated with older age, female gender, poor differentiation, advanced tumor stage, lymph node metastasis, distant metastasis, and advanced AJCC stage. Regarding treatment, more SRC patients received surgery, radiotherapy and chemotherapy than non-SRC patients.

\section{Survival}

The median follow-up period was 5 (range 0-270) months for SRC group and 6 (range 0-487) months for non-SRC group. The 1-, 2- and 5-year OS was $28.1 \%$, $16.8 \%$ and $7.2 \%$ for SRC vs. $34.9 \%, 23.1 \%$ and $13.2 \%$ for non-SRC, respectively $(P=0.002)$ (Fig. $2 \mathrm{a})$. The 1 -, 2 - and 5-year CSS was $29.0 \%, 10.3 \%$ and $6.5 \%$ for SRC vs. $33.8 \%$, $17.6 \%$ and $13.3 \%$ for non-SRC, respectively $(P=0.012)$ (Fig. 2b). In multivariable analysis, SRC was an independent determinant of $\mathrm{OS}(\mathrm{HR}=1.256,95 \%$ CI 1.035-1.523, $P=0.021)$ and CSS (HR $=1.211,95 \%$ CI $1.012-1.447$, $P=0.036$ ) (Table 2).

Table 3 summarizes the characteristics of the patients in the PSM analysis. There were no differences in baseline confounding variables between the two groups. After matching, SRC still had prognostic value for OS $(\mathrm{HR}=1.341,95 \% \mathrm{CI} 1.006-1.687, P=0.012)$ and CSS $(\mathrm{HR}=1.625,95 \%$ CI $1.162-2.273, P=0.005)$. The 5-year OS in patients with SRC was $8.0 \%$ compared with $14.9 \%$ in patients with non-SRC. The 5-year CCS in patients

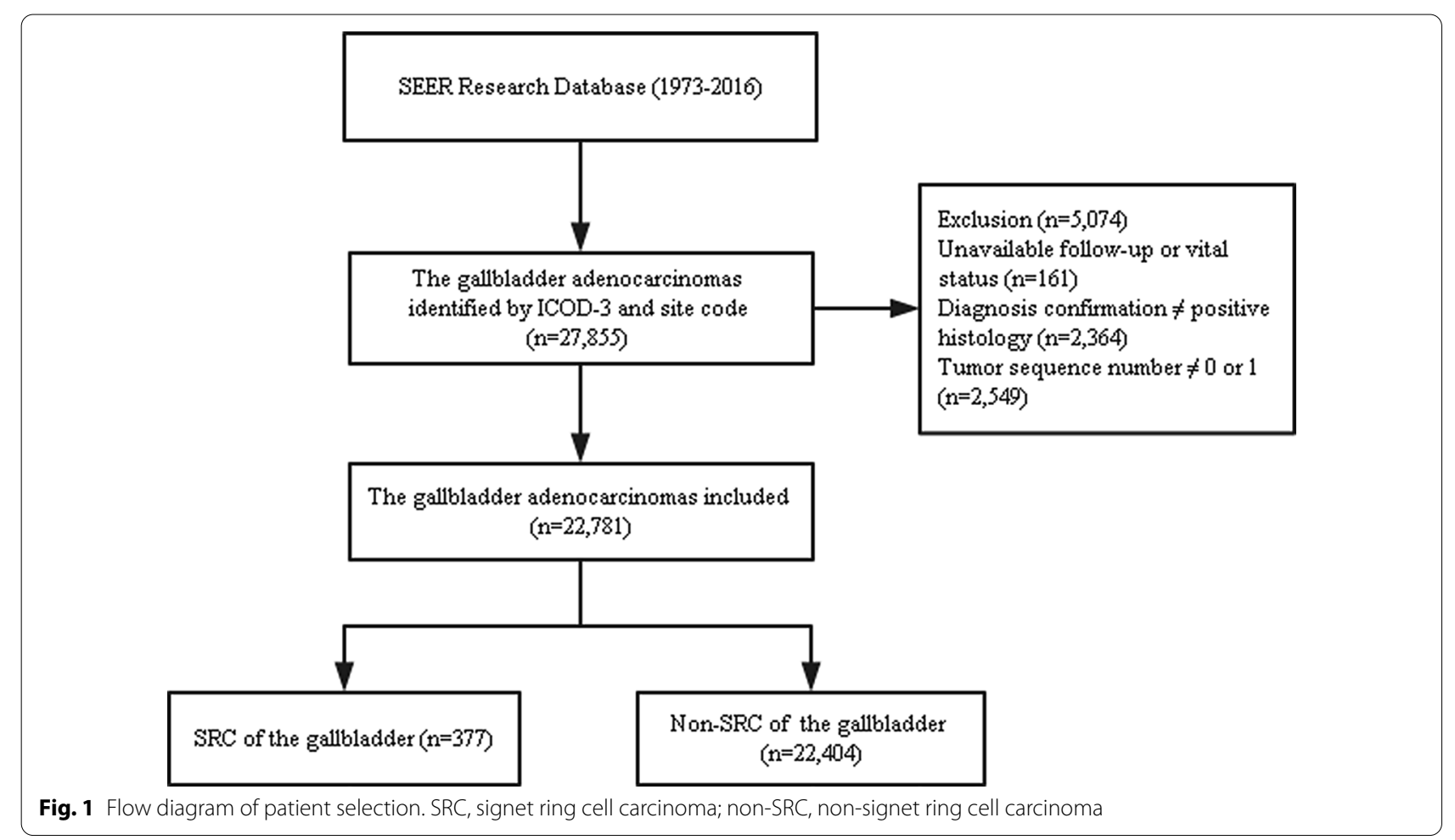


Table 1 Baseline demographic and clinicopathological characteristics of patients with SRC vs. non-SRC

\begin{tabular}{|c|c|c|c|}
\hline Parameters & $\mathrm{SRC}(\mathrm{n}=377)$ & $\begin{array}{l}\text { Non-SRC } \\
(n=22,404)\end{array}$ & $P$ Value \\
\hline \multicolumn{4}{|l|}{ Age, years } \\
\hline$<60$ & $83(22.0 \%)$ & $6954(31.0 \%)$ & \multirow[t]{2}{*}{$<0.001$} \\
\hline$\geq 60$ & $294(78.0 \%)$ & $15,450(69.0 \%)$ & \\
\hline \multicolumn{4}{|l|}{ Sex } \\
\hline Male & $88(23.3 \%)$ & $6625(29.6 \%)$ & \multirow[t]{2}{*}{0.009} \\
\hline Female & $289(76.7 \%)$ & $15,779(70.4 \%)$ & \\
\hline \multicolumn{4}{|l|}{ Race } \\
\hline White & $291(77.2 \%)$ & $17,781(79.4 \%)$ & \multirow[t]{3}{*}{0.535} \\
\hline Black & $44(11.7 \%)$ & $2264(10.1 \%)$ & \\
\hline Other & $42(11.1 \%)$ & $2359(10.5 \%)$ & \\
\hline \multicolumn{4}{|l|}{ Clinical T-stage } \\
\hline $\mathrm{T} 1-\mathrm{T} 2$ & $87(23.1 \%)$ & $4750(21.2 \%)$ & \multirow[t]{3}{*}{$<0.001$} \\
\hline T3-T4 & $121(32.1 \%)$ & $5248(23.4 \%)$ & \\
\hline Unknown & $169(44.8 \%)$ & $12,406(55.4 \%)$ & \\
\hline \multicolumn{4}{|c|}{ Lymph node metastasis } \\
\hline No & 115 (30.5\%) & $6802(30.4 \%)$ & \multirow[t]{3}{*}{$<0.001$} \\
\hline Yes & $91(24.1 \%)$ & $3158(14.1 \%)$ & \\
\hline Unknown & $171(45.4 \%)$ & $12,444(55.5 \%)$ & \\
\hline \multicolumn{4}{|l|}{ Distant metastasis } \\
\hline No & $133(35.3 \%)$ & $6693(29.9 \%)$ & \multirow[t]{3}{*}{$<0.001$} \\
\hline Yes & $93(24.7 \%)$ & $4445(19.8 \%)$ & \\
\hline Unknown & $151(40.1 \%)$ & $11,266(50.3 \%)$ & \\
\hline \multicolumn{4}{|l|}{ AJCC stage } \\
\hline$|-| \mid$ & $118(31.3 \%)$ & $5811(25.9 \%)$ & \multirow[t]{3}{*}{$<0.001$} \\
\hline III-IV & 105 (27.9\%) & $5054(22.6 \%)$ & \\
\hline Unknown & $154(40.8 \%)$ & $11,539(51.5 \%)$ & \\
\hline \multicolumn{4}{|l|}{ Histologic grade } \\
\hline Well-moderate & $23(6.1 \%)$ & $8629(38.5 \%)$ & \multirow[t]{3}{*}{$<0.001$} \\
\hline Poor-undifferentiated & $269(71.4 \%)$ & $6588(29.4 \%)$ & \\
\hline Unknown & 85 (22.5\%) & $7187(32.1 \%)$ & \\
\hline \multicolumn{4}{|l|}{ Surgery } \\
\hline Yes & $246(65.3 \%)$ & $7138(31.9 \%)$ & \multirow[t]{3}{*}{$<0.001$} \\
\hline No & $66(17.5 \%)$ & 3556 (15.9\%) & \\
\hline Unknown & $65(17.2 \%)$ & $11,710(52.3 \%)$ & \\
\hline \multicolumn{4}{|l|}{ Radiotherapy } \\
\hline Yes & $52(13.8 \%)$ & 2354 (10.5\%) & \multirow[t]{2}{*}{0.04} \\
\hline No & $325(86.2 \%)$ & 20,050 (89.5\%) & \\
\hline \multicolumn{4}{|l|}{ Chemotherapy } \\
\hline Yes & $125(33.2 \%)$ & $6006(26.8 \%)$ & \multirow[t]{2}{*}{0.006} \\
\hline No & $252(66.8 \%)$ & $16,398(73.2 \%)$ & \\
\hline \multicolumn{4}{|l|}{ Year of diagnosis } \\
\hline 1975-2009 & $249(66.0 \%)$ & $15,676(70.0 \%)$ & \multirow[t]{2}{*}{0.100} \\
\hline 2010-2016 & $128(34.0 \%)$ & $6728(30.0 \%)$ & \\
\hline Marital status & & & \\
\hline Married & $183(48.5 \%)$ & $11,854(52.9 \%)$ & 0.092 \\
\hline Unmarried & $194(51.5 \%)$ & $10,550(47.1 \%)$ & \\
\hline
\end{tabular}

$S R C$ signet ring cell carcinoma, AJCC American Joint Committee on Cancer with SRC was $8.5 \%$ compared with $13.4 \%$ in patients with non-SRC.

The effect of treatment types were further analysed. Of the 377 gallbladder SRC patients, 99 with undefined treatment information were excluded. In the remaining 278 patients, 153 (55\%) received surgery alone, $14(5 \%)$ received surgery in combination with radiotherapy, 79 $(28.4 \%)$ received surgery in combination with chemotherapy, and $32(11.5 \%)$ received chemotherapy alone. Comparison of OS between patients who underwent surgery and those who received chemotherapy alone showed that the long-term survival of patients who received surgery in combination with chemotherapy, but not with radiotherapy, were significantly better than those who received surgery or chemotherapy alone (Table 4).

\section{Discussion}

The clinicopathological characteristics and prognosis of patients with gallbladder SRC remain unclear, possibly because of its rarity. Current knowledge about gallbladder SRC is mainly extrapolated from anecdotal case reports, with limited statistical power [6-17]. It is therefore necessary to undertake an analysis on gallbladder SRC based on large databases such as SEER that can provide a more comprehensive and larger sample size cohort of patients. To the best of our knowledge, this is the first population-based analysis to describe the clinicopathological characteristics, prognosis and treatment strategies specific to gallbladder SRC.

In this large population-based study, 22,781 patients with gallbladder adenocarcinomas (SRC and non-SRC) were identified from the SEER database, of whom 1.7\% patients were diagnosed with gallbladder SRC. The mean age of the SRC patients was 69.0 years in our cohort, similar to the mean age of 61.3 (range 22-86) years reported in the previous articles [6-17]. Contrary to the finding of male predilection for primary SRC in other sites, such as the pancreas and colon, our study showed that the male-female ratio was 0.30 for gallbladder SRC, presenting a female predilection [18-21]. This difference may be caused by the female-predilection nature of gallbladder carcinoma itself [22]. Among this cohort, we found that patients with gallbladder SRC were more significantly associated with older age, female gender, poor differentiation, advanced tumor stage, lymph node metastasis, distant metastasis, and advanced AJCC stage than those with non-SRC. When adjusting for other clinical and demographical features that were available, SRC was identified as an independent negative prognostic factor in patients with gallbladder adenocarcinomas. Although SRC exhibits dedifferentiated, highly malignant and aggressive properties, its mechanism remains unclear. 

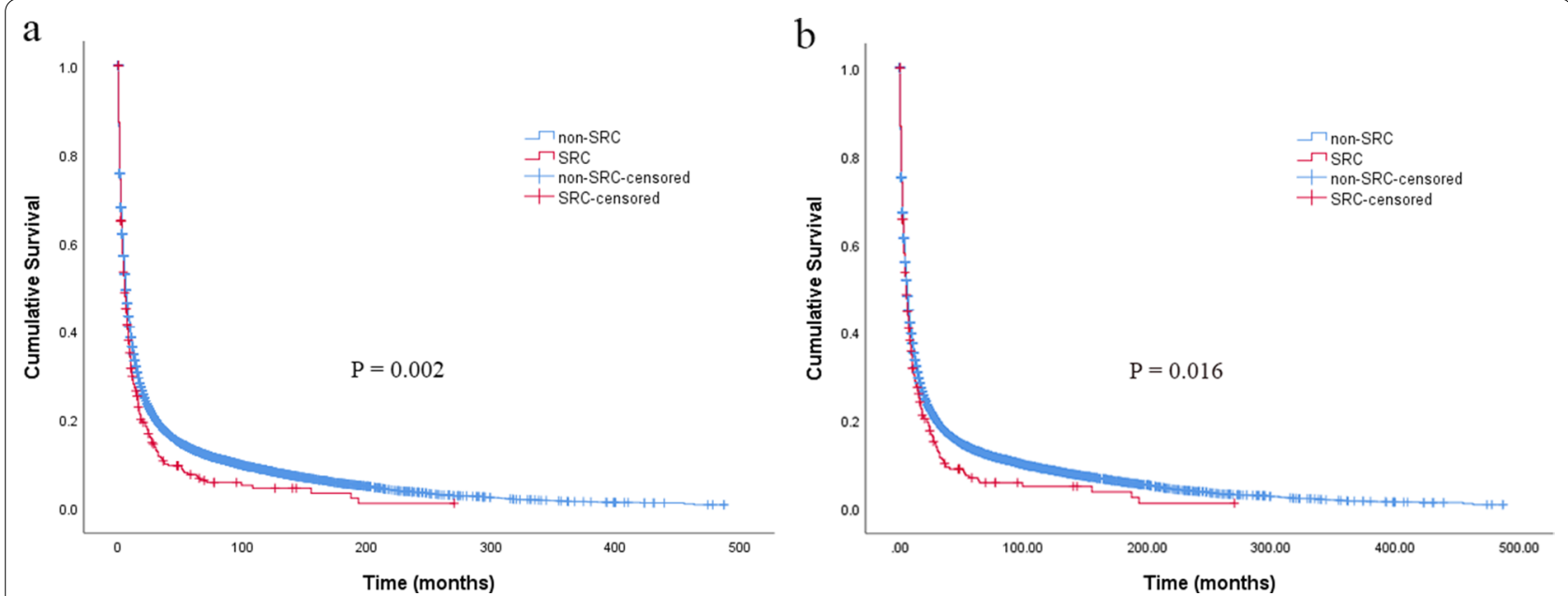

Fig. 2 Overall survival (a) and cancer-specific survival (b) of patients with signet ring cell carcinoma and non-signet ring cell carcinoma

Previous articles have reported that the abnormal activation of ErbB2/ErbB3 or loss of E-cadherin and MUC4 may deprive signet ring cells of the ability to maintain cell-to-cell contact, thereby promoting invasion and metastasis [23-26]. This mechanism may partly explain the high metastasis rate and poor prognosis of SRC, as derived from our analyses.

Given the poor prognosis of gallbladder SRC, it is necessary to find an optimal treatment strategy. Total tumor excision with adjuvant chemoradiotherapy is the mainstay of treatment for gallbladder adenocarcinomas at present $[27,28]$. However, no standardized protocol and guideline for the treatment of gallbladder SRC are available at present because of the limited number of cases and studies. In the previous 12 cases reported, five patients underwent surgery with chemotherapy $[6,8,10,13,17]$, three underwent surgery alone $[7,9,12]$, one underwent surgery with chemoradiotherapy [14], two received no treatment $[11,15]$, and one had no detail information [16]. In our analysis, we found that patients who underwent surgery, with or without chemotherapy or radiotherapy, had better survival than those who received chemotherapy alone (Table 4). When compared with surgery alone, we found an interesting trend, showing that patients who underwent surgery with chemotherapy had significantly improved OS $(P=0.036)$, whereas no difference in OS was shown in patients who underwent surgery with radiotherapy $(P=0.467)$, suggesting that surgery with chemotherapy may be the optimal treatment for gallbladder SRC, which is consistent with the traditional management strategy of SRC in other sites [29-31]. As for adjuvant radiotherapy, no benefit was obtained in our study, and a similar result was also reported in a study involving 51 patients with stage II rectal SRC [32]. In addition, previous studies have reported that SRC histology seems associated with resistance to radiotherapy in patients with cervical and esophageal adenocarcinoma $[33,34]$. Therefore, adjuvant radiotherapy is not recommended for routine treatment of SRC.

The present study represents the first and largest study on gallbladder SRC to date, but several limitations remain. Firstly, selection bias could not be ignored due to the retrospective nature of the study. In addition, some important information about therapies was not recorded in the SEER database, such as the radiation dosage and chemotherapy regimens. Meanwhile, some important variables associated with survival, including co-morbidities and the resection margin status, which would greatly impact survival, were also not accessible. Finally, we did not study the effect of radiotherapy alone on survival, for no patient in our cohort received radiotherapy alone. Despite these limitations, the results of this study can still provide clinicians with deeper insights into this rare tumor.

\section{Conclusion}

SRC of the gallbladder has a worse prognosis than nonSRC, with poorer differentiation, and a more advanced stage. Surgery with chemotherapy is the main treatment strategy to improve survival, which supports the traditional management strategy of SRC. However, no survival advantage was obtained from adjuvant radiotherapy in the current study. 
Table 2 Prognostic factors for survival

\begin{tabular}{|c|c|c|c|c|c|c|c|c|}
\hline \multirow[t]{3}{*}{ Characteristic } & \multicolumn{4}{|l|}{ Overall survival } & \multicolumn{4}{|c|}{ Cancer-specific survival } \\
\hline & \multicolumn{2}{|l|}{ Univariate analysis } & \multicolumn{2}{|l|}{ Multivariate a } & \multicolumn{2}{|l|}{ Univariate Analysis } & \multicolumn{2}{|c|}{ Multivariate analysis } \\
\hline & $\mathrm{HR}(95 \% \mathrm{Cl})$ & $P$ Value & $\mathrm{HR}(95 \% \mathrm{Cl})$ & $P$ Value & $\mathrm{HR}(95 \% \mathrm{Cl})$ & $P$ Value & $\mathrm{HR}(95 \% \mathrm{Cl})$ & $P$ Value \\
\hline \multicolumn{9}{|l|}{ Age, years } \\
\hline$\leq 60$ & Reference & & Reference & & Reference & & Reference & \\
\hline$>60$ & $1.428(1.384-1.473)$ & 0.001 & $1.484(1.383-1.594)$ & 0.001 & $1.516(1.459-1.575)$ & 0.001 & $1.357(1.266-1.456)$ & 0.001 \\
\hline \multicolumn{9}{|l|}{ Sex } \\
\hline Male & Reference & & Reference & & Reference & & Reference & \\
\hline Female & $0.950(0.922-0.980)$ & 0.001 & $0.894(0.833-0.960)$ & 0.002 & $0.953(0.923-0.984)$ & 0.003 & $0.900(0.845-0.959)$ & 0.001 \\
\hline \multicolumn{9}{|l|}{ Race } \\
\hline White & Reference & & Reference & & Reference & & Reference & \\
\hline Black & $0.980(0.935-1.027)$ & 0.395 & $1.065(0.965-1.175)$ & 0.210 & $0.967(0.920-1.016)$ & 0.182 & $0.995(0.913-1.085)$ & 0.914 \\
\hline Other & $0.847(0.808-0.888)$ & $<0.001$ & $0.907(0.815-1.009)$ & 0.073 & $0.862(0.822-0.905)$ & $<0.001$ & $0.882(0.804-0.967)$ & 0.008 \\
\hline \multicolumn{9}{|l|}{ Clinical T-stage } \\
\hline $\mathrm{T} 1-2$ & Reference & & & & Reference & & & \\
\hline T3-4 & $2.710(2.584-2.841)$ & $<0.001$ & & & $2.636(2.504-2.774)$ & $<0.001$ & & \\
\hline \multicolumn{9}{|c|}{ Lymph node metastasis } \\
\hline No & Reference & & & & Reference & & & \\
\hline Yes & $1.425(1.359-1.494)$ & $<0.001$ & & & $1.406(1.337-1.479)$ & $<0.001$ & & \\
\hline \multicolumn{9}{|l|}{ Distant metastasis } \\
\hline No & Reference & & & & Reference & & & \\
\hline Yes & $3.101(2.965-3.244)$ & $<0.001$ & & & $3.031(2.889-3.180)$ & $<0.001$ & & \\
\hline \multicolumn{9}{|l|}{ AJCC clinical stage } \\
\hline$|-| \mid$ & Reference & & Reference & & Reference & & Reference & \\
\hline III-IV & $3.210(3.066-3.361)$ & $<0.001$ & $2.807(2.519-3.041)$ & $<0.001$ & $3.105(2.956-3.261)$ & $<0.001$ & $2.816(2.622-3.023)$ & $<0.001$ \\
\hline \multicolumn{9}{|l|}{ Surgery } \\
\hline No & Reference & & Reference & & Reference & & Reference & \\
\hline Yes & $0.370(0.355-0.387)$ & $<0.001$ & $0.575(0.519-0.637)$ & $<0.001$ & $0.345(0.332-0.359)$ & $<0.001$ & $0.525(0.481-0.573)$ & $<0.001$ \\
\hline \multicolumn{9}{|l|}{ Radiation } \\
\hline No & Reference & & Reference & & Reference & & Reference & \\
\hline Yes & $0.605(0.578-0.634)$ & $<0.001$ & $0.908(0.820-1.006)$ & 0.065 & $0.602(0.573-0.632)$ & $<0.001$ & $0.966(0.882-1.057)$ & 0.450 \\
\hline \multicolumn{9}{|l|}{ Chemotherapy } \\
\hline No & Reference & & Reference & & Reference & & Reference & \\
\hline Yes & $0.848(0.821-0.875)$ & $<0.001$ & $0.801(0.738-0.869)$ & $<0.001$ & $0.837(0.810-0.865)$ & $<0.001$ & $0.673(0.627-0.722)$ & $<0.001$ \\
\hline \multicolumn{9}{|l|}{ Histologic grade } \\
\hline Well-moderate & Reference & & Reference & & Reference & & Reference & \\
\hline Poor-undifferentiated & 1.838 (1.774-1.903) & $<0.001$ & $1.632(1.527-1.745)$ & $<0.001$ & $1.826(1.759-1.894)$ & $<0.001$ & $1.686(1.589-1.789)$ & $<0.001$ \\
\hline \multicolumn{9}{|l|}{ Histology } \\
\hline Non-SRC & Reference & & Reference & & Reference & & Reference & \\
\hline SRC & $1.184(1.063-1.320)$ & 0.002 & $1.256(1.035-1.523)$ & 0.021 & $1.157(1.027-1.304)$ & 0.016 & $1.211(1.012-1.447)$ & 0.036 \\
\hline \multicolumn{9}{|l|}{ Year of diagnosis } \\
\hline 1998-2009 & Reference & & Reference & & Reference & & Reference & \\
\hline 2010-2016 & $0.796(0.771-0.823)$ & $<0.001$ & $0.912(0.848-0.981)$ & 0.013 & $0.800(0.773-0.828)$ & $<0.001$ & $0.884(0.834-0.937)$ & $<0.001$ \\
\hline \multicolumn{9}{|l|}{ Marital status } \\
\hline Unmarried & Reference & & Reference & & Reference & & Reference & \\
\hline Married & $0.819(0.796-0.842)$ & $<0.001$ & $0.865(0.809-0.924)$ & $<0.001$ & $1.249(1.213-1.286)$ & $<0.001$ & $1.221(1.151-1.295)$ & $<0.001$ \\
\hline
\end{tabular}

HR hazard ratio, Cl confidence interval, AJCC American Joint Committee on Cancer, SRC signet ring cell carcinoma 
Table 3 Patient characteristics after propensity score matching

\begin{tabular}{|c|c|c|c|}
\hline & $\operatorname{SRC}(n=245)$ & Non-SRC $(n=245)$ & $P$ Value \\
\hline \multicolumn{4}{|l|}{ Age, years } \\
\hline$\leq 60$ & $56(22.9 \%)$ & $49(20.0 \%)$ & \multirow[t]{2}{*}{0.441} \\
\hline$>60$ & $189(77.1 \%)$ & $196(80.0 \%)$ & \\
\hline \multicolumn{4}{|l|}{ Sex } \\
\hline Male & $59(24.1 \%)$ & $62(25.3 \%)$ & \multirow[t]{2}{*}{0.753} \\
\hline Female & $186(75.9 \%)$ & $183(74.7 \%)$ & \\
\hline \multicolumn{4}{|l|}{ Race } \\
\hline White & $194(79.2 \%)$ & $181(73.9 \%)$ & \multirow[t]{3}{*}{0.097} \\
\hline Black & $28(11.4 \%)$ & $29(11.8 \%)$ & \\
\hline Other & $23(9.4 \%)$ & $35(11.3 \%)$ & \\
\hline \multicolumn{4}{|l|}{ AJCC stage } \\
\hline$|-| \mid$ & $110(44.9 \%)$ & $110(44.9 \%)$ & \multirow[t]{3}{*}{1.000} \\
\hline III-IV & $73(29.8 \%)$ & $73(29.8 \%)$ & \\
\hline Unknown & $62(25.3 \%)$ & $62(25.3 \%)$ & \\
\hline \multicolumn{4}{|l|}{ Histologic grade } \\
\hline Well-moderate & $18(7.3 \%)$ & $18(7.3 \%)$ & \multirow[t]{2}{*}{1.000} \\
\hline Poor-undifferentiated & $227(92.7 \%)$ & $227(92.7 \%)$ & \\
\hline \multicolumn{4}{|l|}{ Surgery } \\
\hline Yes & $219(89.4 \%)$ & $220(89.8 \%)$ & \multirow[t]{2}{*}{0.882} \\
\hline No & $26(10.6 \%)$ & $25(10.2 \%)$ & \\
\hline \multicolumn{4}{|l|}{ Radiotherapy } \\
\hline Yes & $38(15.5 \%)$ & $30(12.2 \%)$ & \multirow[t]{2}{*}{0.296} \\
\hline No & $207(84.5 \%)$ & $215(87.8 \%)$ & \\
\hline \multicolumn{4}{|l|}{ Chemotherapy } \\
\hline Yes & 85 (34.7\%) & $91(37.1 \%)$ & \multirow[t]{2}{*}{0.572} \\
\hline No & $160(65.3 \%)$ & $154(62.9 \%)$ & \\
\hline \multicolumn{4}{|l|}{ Year of diagnosis } \\
\hline 1975-2009 & $142(58.0 \%)$ & $60(24.5 \%)$ & \multirow[t]{2}{*}{$<0.001$} \\
\hline 2010-2016 & $103(42.0 \%)$ & $185(75.5 \%)$ & \\
\hline \multicolumn{4}{|l|}{ Marital status } \\
\hline Married & $127(51.8 \%)$ & $119(48.6 \%)$ & \multirow[t]{2}{*}{0.471} \\
\hline Unmarried & $118(48.2 \%)$ & $126(51.4 \%)$ & \\
\hline
\end{tabular}

$S R C$ signet ring cell carcinoma, AJCC American Joint Committee on Cancer

Table 4 Prognosis of patient with signet ring cell carcinoma stratified by treatment

\begin{tabular}{|c|c|c|c|c|c|c|c|}
\hline Variables & $\mathbf{N}$ & $\begin{array}{l}\text { Age, years } \\
>60\end{array}$ & Male & $\begin{array}{l}\text { AJCC } \\
\text { III-IV stage }\end{array}$ & $\begin{array}{l}\text { 5-year OS } \\
(\%)\end{array}$ & $\mathrm{HR}(95 \% \mathrm{Cl})$ & $P$ value \\
\hline Whole group & 278 & & & & & & \\
\hline CT alone & 32 & $25(78.1 \%)$ & $4(12.5 \%)$ & $22(68.8 \%)$ & 0 & Reference & \\
\hline Surgery alone & 153 & $122(79.7 \%)$ & 39 (25.5\%) & 37 (24.2\%) & 7.8 & $0.605(0.403-0.909)$ & 0.015 \\
\hline Surgery+RT & 14 & $13(92.9 \%)$ & $6(42.9 \%)$ & $1(7.1 \%)$ & 0 & $0.478(0.244-0.937)$ & 0.032 \\
\hline Surgery $+\mathrm{CT}$ & 79 & $50(63.3 \%)$ & 15 (19.0\%) & 27 (34.2\%) & 8.6 & $0.433(0.279-0.671)$ & $<0.001$ \\
\hline Surgery group & 246 & & & & & & \\
\hline Surgery alone & 153 & $122(79.7 \%)$ & 39 (25.5\%) & $37(24.2 \%)$ & 7.8 & Reference & \\
\hline Surgery+RT & 14 & $13(92.9 \%)$ & $6(42.9 \%)$ & $1(7.1 \%)$ & 0 & $0.802(0.444-1.451)$ & 0.467 \\
\hline Surgery $+\mathrm{CT}$ & 79 & $50(63.3 \%)$ & $15(19.0 \%)$ & $27(34.2 \%)$ & 8.6 & $0.726(0.538-0.980)$ & 0.036 \\
\hline
\end{tabular}

OS overall survival, $H R$ hazard ratio, $C l$ confidence interval, $C T$ chemotherapy, $R T$ radiotherapy,

AJCC American Joint Committee on Cancer 


\section{Abbreviations}

SRC: Signet ring cell carcinoma; OS: Overall survival; HR: Hazard ratio; Cl: Confidence interval; SEER: Surveillance, epidemiology, and end results; AJCC: American Joint Committee on Cancer.

\section{Acknowledgements}

We appreciate Doctor Yanfang Zhao (Department of Health Statistics, Second Military Medical University, Shanghai, China) for her critical revision of the statistical analysis section.

\section{Authors' contributions}

WS and ZY designed the study. WS, LJ and YJ collected analyzed the data. WS, $L J$ and $Y J$ wrote the manuscript and $Z Y$ critically reviewed the manuscript. All authors read and approved the final manuscript.

\section{Funding}

Not applicable.

\section{Availability of data and materials}

The data that support the findings of this study were abstracted from an open database, the Surveillance, Epidemiology, and End Results (SEER) database (https://seer.cancer.gov).

\section{Declarations}

\section{Ethics approval and consent to participate}

This study was approved by the institutional review board of The First Affiliated Hospital of Xiamen University. Consent to participate was waived as SEER data is publicly available.

\section{Consent for publication}

Not applicable.

\section{Competing interests}

The authors declare that they have no competing interests.

Received: 25 January 2021 Accepted: 24 May 2021

Published online: 06 June 2021

\section{References}

1. Arai T. Where does signet-ring cell carcinoma come from and where does it go? Gastric Cancer. 2019;22:651-2.

2. Wu SG, Chen XT, Zhang WW, et al. Survival in signet ring cell carcinoma varies based on primary tumor location: a Surveillance, Epidemiology, and End Results database analysis. Expert Rev Gastroenterol Hepatol. 2018;12:209-14

3. Chen J, Cai R, Ren G, et al. Differences in clinicopathological characteristics and computed tomography findings between signet ring cell carcinoma and nonsignet ring cell carcinoma in early and advanced gastric cancer. Cancer Med. 2018;7:1160-9.

4. Peng J, Xiao P, Liao B, Ye J, He Y. Analysis of clinicopathological features of 1879 cases of gastric cancer in Southern China: a single center experience. Chinese journal of surgery. 2014:52:168-70.

5. Bamboat ZM, Tang LH, Vinuela E, et al. Stage-stratified prognosis of signet ring cell histology in patients undergoing curative resection for gastric adenocarcinoma. Ann Surg Oncol. 2014;21:1678-85.

6. Hiraki M, Ueda J, Kai K, et al. A case of signet ring cell carcinoma of the gallbladder which was treated by aggressive surgery and intensive adjuvant chemotherapy. J Gastrointest Cancer. 2017;48:83-6.

7. Bazan F, Sanchez J, Aguilar G, et al. Metastatic gallbladder adenocarcinoma with signet-ring cells: a case report. J Med Case Rep. 2011;5:458

8. Mondal SK. Signet ring cell carcinoma of gallbladder with celiac lymph node metastasis in a young man. J Cancer Res Ther. 2010;6:379-81.

9. Pudasainin S, Subedi N, Prasad KB, et al. Signet ring cell carcinoma of the gallbladder: a case report. Nepal Med Coll J. 2011;13:308-10.

10. Karabulut Z, Yildirim Y, Abaci I, Ilgici D, Ozyilkan O. Signet-ring cell carcinoma of the gallbladder: a case report. Adv Ther. 2008;25:520-3.
11. Nishida T, Iwasaki H, Johzaki H, Tanaka S, Watanabe R, Kikuchi M. A human gall-bladder signet ring cell carcinoma cell line. Pathol Int. 1997:47:368-76.

12. Pavić I, Marusić Z, Mijić A, Balicević D, Kruslin B, Tomas D. A case of signet-ring cell carcinoma of the gallbladder: immunohistochemistry and differential diagnosis. Acta Clin Croat. 2010;49:159-62.

13. Czyszczon IA, Alatassi $H$. Signet ring cell carcinoma of the gallbladder in a 22-year-old man: a case report and review of the literature. Int J Surg Pathol. 2010;18:358-62.

14. Krunic AL, Chen HM, Lopatka K. Signet-ring cell carcinoma of the gallbladder with skin metastases. Australas J Dermatol. 2007;48:187-9.

15. Brandt-Rauf PW, Branwood AW. Case report: an unusual case of gallbladder cancer in an automotive worker. CA Cancer J Clin. 1980;30:333-6.

16. Khoo JJ, Nurul AM. A clinicopathological study of nine cases of gallbladder carcinoma in 1122 cholecystectomies in Johor. Malaysia Malays J Pathol. 2008:30:21-6.

17. Maeda T, Sano O, Yamanaka T, Beppu T, Matsuda T, Ogawa M. A case of unresectable advanced gall bladder cancer successfully treated by hepatic arterial chemotherapy with reservoir (HACR) using CDDP and 5-FU. Gan To Kagaku Ryoho. 1999;26:1913-6.

18. Belli S, Aytac HO, Karagulle E, Yabanoglu H, Kayaselcuk F, Yildirim S. Outcomes of surgical treatment of primary signet ring cell carcinoma of the colon and rectum: 22 cases reviewed with literature. Int Surg. 2014:99:691-8.

19. Piessen G, Messager M, Lefevre JH, et al. Signet ring cell adenocarcinomas: different clinical-pathological characteristics of oesophageal and gastric locations. Eur J Surg Oncol. 2014;40:1746-55.

20. Liu X, Cai H, Sheng W, et al: Clinicopathological characteristics and survival outcomes of primary signet ring cell carcinoma in the stomach: retrospective analysis of single center database. PLoS One. 2015;10:e0144420.

21. Patel M, Hans HS, Pan K, Khan H, Donath E, Caldera H. The impact of epidemiological factors and treatment interventions on survival in patients with signet ring cell carcinoma of the pancreas. Am J Clin Oncol. 2018:41:1176-84

22. Kumar R, Srinivasan R, Gupta N, et al. Spectrum of gallbladder malignancies on fine-needle aspiration cytology: 5 years retrospective single institutional study with emphasis on uncommon variants. Diagn Cytopathol. 2017;45:36-42.

23. Carraway KL, Theodoropoulos G, Kozloski GA, Carothers Carraway CA. Muc4/MUC4 functions and regulation in cancer. Future Oncol. 2009:5:1631-40.

24. Fukui Y. Mechanisms behind signet ring cell carcinoma formation. Biochem Biophys Res Commun. 2014;450:1231-3.

25. Yokoyama A, Shi BH, Kawai T, et al. Muc4 is required for activation of ErbB2 in signet ring carcinoma cell lines. Biochem Biophys Res Commun. 2007;355(1):200-3.

26. Lim MG, Adsay NV, Grignon DJ, Osunkoya AO. E-cadherin expression in plasmacytoid, signet ring cell and micropapillary variants of urothelial carcinoma: comparison with usual-type high-grade urothelial carcinoma. Mod Pathol. 2011:24:241-7.

27. Cong LL, Cai ZQ, Guo P, et al. Decision of surgical approach for advanced gallbladder adenocarcinoma based on a Bayesian network. J Surg Oncol. 2017;116:1123-31.

28. Geng ZM, Cai ZQ, Zhang Z, et al. Estimating survival benefit of adjuvant therapy based on a Bayesian network prediction model in curatively resected advanced gallbladder adenocarcinoma. World J Gastroenterol. 2019;25:5655-66.

29. Wang T, Shen B, Wang L, Liu F: Primary signet ring cell carcinoma of the breast: A rare entity with unique biological behavior-A clinical study based on pure signet ring cell carcinoma cohort. Pathol Res Pract. 2020:216:152948.

30. Ling CR, Wang R, Wang MJ, Ping J, Zhuang W. Prognosis and value of preoperative radiotherapy in locally advanced rectal signet-ring cell carcinoma. Sci Rep. 2017;7:45334.

31. Shi T, Song $X$, Liu $Q$, et al. Survival benefit of palliative gastrectomy followed by chemotherapy in stage IV gastric signet ring cell carcinoma patients: a large population-based study. Cancer Med. 2019:8(13):6010-20. 
32. Wu SG, Zhang WW, Sun JY, He ZY, Su GQ, Li FY. Preoperative radiotherapy improves survival in rectal signet-ring cell carcinoma-a population-based study. Radiat Oncol. 2017;12:141.

33. Okada S, Tsuda H, Ohmi K, et al. Immature glandular features in squamous cell carcinoma of the uterine cervix as an independent indicator of resistance to radiotherapy. Int J Gynecol Cancer. 2002;12:277-85.
34. Patel VR, Hofstetter WL, Correa AM, et al. Signet ring cells in esophageal adenocarcinoma predict poor response to preoperative chemoradiation. Ann Thorac Surg. 2014;98:1064-71.

\section{Publisher's Note}

Springer Nature remains neutral with regard to jurisdictional claims in published maps and institutional affiliations.
Ready to submit your research? Choose BMC and benefit from:

- fast, convenient online submission

- thorough peer review by experienced researchers in your field

- rapid publication on acceptance

- support for research data, including large and complex data types

- gold Open Access which fosters wider collaboration and increased citations

- maximum visibility for your research: over $100 \mathrm{M}$ website views per year

At BMC, research is always in progress.

Learn more biomedcentral.com/submissions 